\title{
Let sleeping dogs lie: a surprising chest X-ray in the paediatric emergency department
}

\author{
Tejshri Shah, ${ }^{1}$ Jacqueline Le Geyt, ${ }^{2}$ Jane Atkins ${ }^{3}$
}

${ }^{1}$ Department of Paediatric Infectious Diseases, Great Ormond Street Hospital, London, UK

${ }^{2}$ Department of Paediatrics, North Middlesex Hosptial, London, UK

${ }^{3}$ Department of Paediatric Cardiothoracic Surgery, Great Ormond Street Hospital, London, UK

\section{Correspondence to} Dr Jacqueline Le Geyt, jacquilegeyt@hotmail.com

Accepted 3 April 2014
CrossMark

To cite: Shah T, Le Geyt J, Atkins J. BMJ Case Rep Published online: [please include Day Month Year] doi:10.1136/bcr-2014203973

\section{DESCRIPTION}

A 7-year-old Bulgarian boy, who had lived in the UK for 18 months, presented with 1 week of cough, fever, intermittent pleuritic pain and 2 months of weight loss. He had a recent trip to Bulgaria, did not own any pets and had not visited any farms. Examination and blood investigations were unremarkable, except for fever. His chest X-ray (figure 1) and CT scan (figure 2) revealed two large opacities. Although there was a wide differential list, hydatid cysts were strongly suspected given the clinical context, and because the masses were smooth walled and homogeneous, despite the echinococcus serology being negative on two occasions. He underwent bilateral cyst excision and the diagnosis was confirmed. He received praziquantel for a fortnight preoperatively and postoperatively and thereafter a 1-year course of albendazole.

The incidence of Echinococcus granulosus is increasing in Europe. ${ }^{1}$ The tapeworm eggs are defaecated by the definitive canine host and are ubiquitous, so easily ingested by children. Cysts develop at a rate of $1-5 \mathrm{~cm}$ per year. The liver and lungs are the most common sites but others include the spleen, central nervous system, bone and kidneys. $^{2}$

Cysts are often found coincidentally on radiological examinations. Symptoms, when they occur, relate to pressure effects but cyst rupture can lead

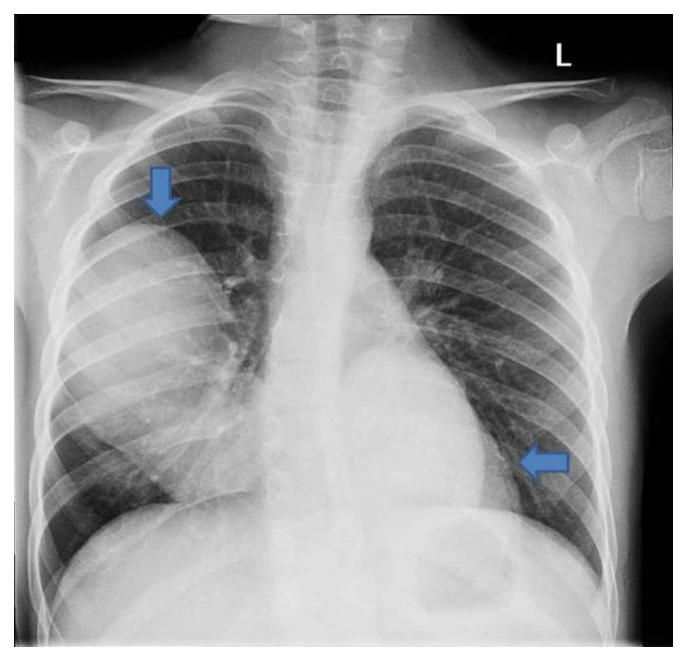

Figure 1 Chest X-ray.

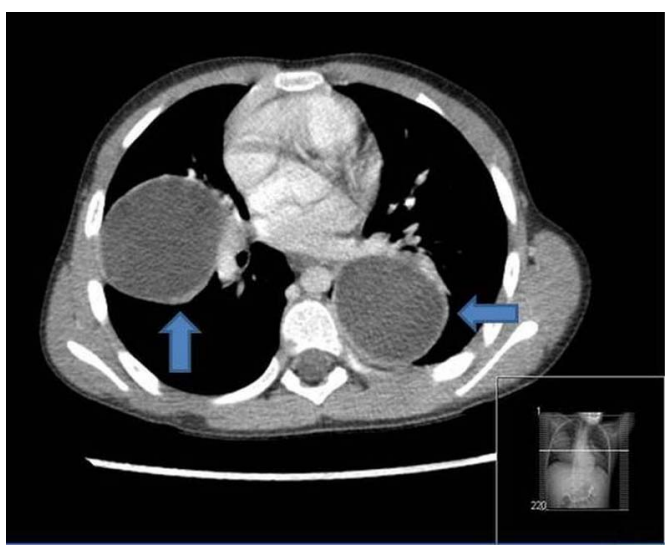

Figure 2 Chest CT scan, axial view.

to fatal anaphylaxis. Serology can help but lacks sensitivity. ${ }^{3}$

\section{Learning points}

- Paediatricians need to be aware of hydatid disease given the increasing incidence.

- Serological tests may be negative.

- Early specialist referral is essential given the potential complications.

Acknowledgements Delane Shingadia (Infectious Diseases) and Nagarajan Muthialu (Cardiothoracic Surgery) had clinical oversight of the case.

Contributors JLG, TS and JA wrote the paper. TS conceived the idea and performed the literature search.

Competing interests None.

Patient consent Obtained.

Provenance and peer review Not commissioned; externally peer reviewed.

\section{REFERENCES}

1 Romig T, Dinkel A, Mackenstedt U. The present situation of echinococcosis in Europe. Parasitol Int 2006;55(Suppl):S187-91.

2 Moro P, Schantz PM. Echinococcosis: a review. Int I Infect Dis 2009:13:125-33

3 Sbihi Y, Rmiqui A, Rodriguez-Cabezas MN, et al. Comparative sensitivity of six serological tests and diagnostic value of ELISA using purified antigen in hydatidosis. J Clin Lab Anal 2001:15:14-18. 
Copyright 2014 BMJ Publishing Group. All rights reserved. For permission to reuse any of this content visit http://group.bmj.com/group/rights-licensing/permissions.

BMJ Case Report Fellows may re-use this article for personal use and teaching without any further permission.

Become a Fellow of BMJ Case Reports today and you can:

- Submit as many cases as you like

- Enjoy fast sympathetic peer review and rapid publication of accepted articles

- Access all the published articles

- Re-use any of the published material for personal use and teaching without further permission

For information on Institutional Fellowships contact consortiasales@bmjgroup.com

Visit casereports.bmj.com for more articles like this and to become a Fellow 